\title{
Kemampuan Bioaktif Glass (Novamin) dan Casein Peptide Amorphous Calcium Phosphate (CPP-ACP) terhadap Demineralisasi Enamel
}

The Potential of Bioactive Glass (Novamin) and Casein Peptide Amorphous Calcium Phosphate (CPP-ACP) on Enamel Demineralization

\section{Jeanny Kathleen H. ${ }^{*}$, Cecilia G.J.Lunardhi**, Ari Subiyanto**}

\begin{abstract}
Background: Oral cavity is always associated with a dynamic atmosphere where the process of demineralization and remineralization will continue to occur. Caries is a pathological state of continuous demineralization process. Prevention of the occurrence of demineralization process can be done by enhancing remineralization, materials that can be used materials that can trigger a process of remineralization include fluoride, cpp-acp, and novamin. Purpose: The aim of this study was to evaluate and compare the potential of bioactive-Glass (Novamin) and casein phosphopeptide-amorphous calcium phosphate (CPP-ACP) containing dentifrice on enamel demineralization. Method: A total of 24 sound human premolars were divided into 4 groups and continued into $\mathrm{pH}$ cycling regime to be evaluated with Scanning Electron Microscope - Energy Dispersive X-Ray. Result: Group D showed significantly higher values $(P<0.05)$ when compared with less demineralization lesion than Group $A, B$, and $C$. Conclusions: The ability of Novamin on demineralization lesions better than CPP-ACP.
\end{abstract}

Keywords: demineralization, remineralization, CPP-ACP, bioactive glass (Novamin).

\section{PENDAHULUAN}

Enamel merupakan lapisan terluar gigi yang paling keras dan inorganik yang sebagian besar disusun oleh kristal hidroksiapatit. Enamel bersifat permeabel terhadap ion-ion dan molekul-molekul yang berasal dari makanan dan minuman yang dikonsumsi. ${ }^{1,2}$ Enamel dapat larut saat berkontak dengan asam sebagian atau keseluruhan, sehingga menyebabkan mineral enamel larut dan menurunkan kekerasan permukaan gigi. Kecepatan kelarutan enamel dipengaruhi oleh derajat keasaman $(\mathrm{pH})$, konsentrasi asam, waktu melarut dan kehadiran ion sejenis kalsium dan fosfat. ${ }^{1,3}$

Permukaan gigi selalu berhubungan dengan suasana yang dinamis dalam rongga mulut, dimana selalu terjadi perubahan kondisi antara demineralisasi dan remineralisasi. Demineralisasi gigi adalah larutnya mineral enamel gigi akibat konsentrasi asam yang mempunyai $\mathrm{pH}$ di bawah 5,5 lebih tinggi pada permukaan enamel dari pada di dalam enamel. ${ }^{4}$ Demineralisasi akan berhenti jika konsentrasi asam rendah dan konsentrasi kalsium atau fosfor dalam saliva kembali tinggi sehingga terjadi proses remineralisasi. ${ }^{1,2}$ Demineralisasi yang terjadi terus-menerus akan mengakibatkan porositas pada permukaan enamel dan mengarah pada terjadinya keadaan patologis. ${ }^{2}$

Bahan anti-karies yang telah lama digunakan adalah fluor. Fluor mempunyai fungsi remineralisasi dengan membentuk mineral fluorapatit melalui reaksi:

$\mathrm{Ca}_{10}\left(\mathrm{PO}_{4}\right)_{6}(\mathrm{OH})_{2}+2 \mathrm{~F} \rightarrow \mathrm{Ca}_{10}\left(\mathrm{PO}_{4}\right)_{6} \mathrm{~F}_{2}+2 \mathrm{OH}$. Selain itu, fluor juga mempunyai fungsi anti-bakteri melalui mekanisme pencegahan karies dengan mengurangi tempat berkembangbiaknya bakteri kariogenik yang sangat berperan dalam 
mencegah timbulnya karies gigi. ${ }^{5}$ Fluoride sangat penting dalam mencegah timbulnya karies dini. Peranan fluoride dalam mencegah karies dengan meningkatkan mineralisasi gigi, mencegah bakteri menghasilkan asam yang dapat memicu terjadinya karies gigi. ${ }^{6}$

Sejak tahun 1990, ketertarikan klinisi akan bahan anti-karies yang berasal dari susu dikenal dengan nama casein phosphopeptide-amorphous calcium phosphate (CPP-ACP) berperan dalam menekan demineralisasi dan meningkatkan proses remineralisasi pada enamel. Efek anti-karies berasal dari bahan multiphosphoseryl pada susu yang mengeluarkan kasein fosfopeptida saat dicerna secara enzimatik. Kasein fosfopeptida memiliki kemampuan besar untuk menstabilkan kalsium fosfat dalam bentuk larutan menjadi amorphous calcium phosphate nanocomplex, yang menghasilkan serpihan CPP-ACP. ${ }^{7}$ Mekanisme antikariogenik yang dihasilkan oleh CPP-ACP merupakan suatu proses terlokalisasinya ion kalsium dan fosfat pada permukaan gigi, sehingga menjaga proses buffer oleh saliva. Hal ini membantu mempertahankan keadaan netral pada enamel gigi, dan akan menurunkan proses demineralisasi, serta meningkatkan remineralisasi. ${ }^{8,9}$

Novamin merupakan bahan bioactive glass yang terbuat dari mineral sintetik yang mengandung sodium, kalsium, fosfor, dan silica (sodium-kalsium-fosfo-silikat) dimana semua mineral ini terdapat dalam tubuh manusia. Kandungan mineral sintetis sodium, kalsium, fosfor, dan silika (sodium kalsium fosfosilikat) berkontak dengan saliva atau air dan secara langsung akan melepaskan ion sodium, kalsium, fosfor kedalam saliva yang berfungsi sebagai remineralisasi pada permukaan gigi. Tidak seperti bahan anti-karies lainnya, Ion - ion yang dilepaskan oleh bioaktif glass akan membentuk hydroxycarbonate apatite (HCA) secara langsung tanpa melalui fase terbentuknya amorphous calcium phosphate intermediate. ${ }^{10}$ Partikel - partikel ini akan melekat pada permukaan gigi, melepaskan ion - ion dan melakukan proses remineralisasi pada permukaan gigi segera setelah diaplikasikan.

Berdasarkan sifat dan manfaat dari kedua bahan tersebut terhadap proses demineralisasi dan remineralisasi, maka perlu dilakukan penelitian seberapa besar kemampuan dari bahan Novamin dibandingkan CPP-ACP terhadap demineralisasi permukaan enamel gigi secara in vitro.

\section{MATERI DAN METODE}

Jenis penelitian eksperimental laboratoris post only control group design.

\section{Alat dan Bahan Penelitian}

Alat :

1. Gelas bekker

2. Cotton bud

3. Scanning Electron Microscope Energy Dispersive X-Ray (SEM$E D X)$

4. Inkubator dengan suhu $37^{\circ} \mathrm{C}$

Bahan :

1. $7,5 \%$ Novamin dan $0,4 \% \quad \mathrm{SnF}_{2}$ $\left(\right.$ Sensodyne ${ }^{\circledR}$ )

2. $10 \%$ Casein PhosphopeptideAmorphous Calcium Phosphate (CPP-ACP) dan 0,2\% NaF dalam GC Tooth Mousse Plus ${ }^{\circledR}$, Itabashi$\mathrm{ku}$, Tokyo, Jepang.

3. Larutan demineralisasi yang terdiri dari : (pH 4,3) (Veerita et al., 2011)

- $2.0 \mathrm{mmol} / \mathrm{l} \mathrm{Ca}$

- $2.0 \mathrm{mmol} / \mathrm{l}$ fosfat

- buffer asam asetat $0.075 \mathrm{~mol} / \mathrm{l}$

4. Larutan remineralisasi yang terdiri dari : (pH 7) (Veerita et al., 2011)

- $1.5 \mathrm{mmol} / \mathrm{l} \mathrm{Ca}$

- $0.9 \mathrm{mmol} / \mathrm{l}$ fosfat 
- 150 mmol/l Potasium klorida

\section{Sampel Penelitian}

Sampel menggunakan elemen gigi premolar tanpa adanya lesi white-spot, dekalsifikasi, atau fluorosis. Bagian permukaan bukal yang tidak sama kecembungannya diratakan dengan menggunakan kertas amplas dengan kehalusan 500, 1000, 1500, dan 5000 mess. Sampel diulasi dengan nail varnish dan meninggalkan enamel tanpa tertutup varnish dengan diameter 3mm. Sampel dilakukan proses demineralisasi selama 96 jam. Semua subyek gigi dibagi menjadi 4 :

- Kelompok 1 : elemen gigi yang telah terdemineralisasi direndam dalam deionized water

- Kelompok 2 : elemen gigi yang telah terdemineralisasi dilakukan $\mathrm{pH}$ cycling.

- Kelompok 3 : elemen gigi yang telah terdemineralisasi diulas dengan Novamin dan dilakukan $\mathrm{pH}$ cycling

- Kelompok 4 : elemen gigi yang telah terdemineralisasi diulas dengan CPP-ACP dan dilakukan $\mathrm{pH}$ cycling.

Semua elemen gigi direndam/diulas selama 2 menit dalam masing - masing perlakuan, kemudian dicuci dengan akuades dan dikeringkan. Kemudian semua elemen gigi dilakukan proses $\mathrm{pH}$ cycling mengikuti metode dari Ittagharun et al., (2010), dengan cara gigi direndam larutan demineralisasi dalam suhu ruangan selama 3 jam. Setiap kelompok direndam dalam larutan demineralisasi dalam gelas bekker yang berbeda. ${ }^{11}$

- Setelah direndam dalam larutan demineralisasi, elemen gigi dicuci dengan akuades dan dikeringkan, kemudian direndam kembali dengan larutan remineralisasi pada suhu ruangan pada gelas bekker yang berbeda selama 2 jam.
- Setelah 2 jam perendaman, gigi dicuci dengan akuades kemudian dikeringkan dan direndam kembali dengan larutan demineralisasi selama 3 jam.

- Semua elemen gigi diberi perlakuan selama 2 menit dalam masing masing kelompok, kemudian dicuci dengan akuades dan dikeringkan, kemudian gigi direndam dalam larutan remineralisasi selama 16 jam.

- Siklus ini diulang selama 10 hari sampai lesi demineralisasi terbentuk, setiap hari larutan demineralisasi dan remineralisasi diganti untuk menjaga keefektivitasan larutan. Nail varnish yang hilang dicat kembali.

- Semua gigi dibersihkan, dicuci dengan akuades, kemudian dikeringkan. Elemen gigi dibelah secara longitudinal dengan ketebalan 2-3mm menggunakan low-speed diamond disc.

- Potongan elemen dikeringkan dan di-coating kemudian dilihat dibawah Scanning Electron Microscope.

- Tiga bagian gambaran tiap gigi diukur menggunakan Image Pro Plus software. Dari sini akan terlihat kedalaman rata - rata sebagai kedalaman demineralisasi.

- Dilakukan juga pengukuran kadar mineral dengan menggunakan SEM EDX.

Hari 1-4 : Demineralisasi 24 sampel, kemudian sampel dibagi menjadi 4 kelompok

Hari 5-14 :

- Kelompok I (kontrol negatif) direndam dalam deionized water

- Kelompok II (kontrol positif) dilakukan $\mathrm{pH}$ cycling

- Kelompok III diberi perlakuan (Novamin $)+\mathrm{pH}$ cycling 
- Kelompok IV diberi perlakuan (CPP-ACP) + pH cycling

\section{HASIL}

Data hasil uji SEM dari pengukuran lesi demineralisasi yang terbentuk pada sampel diperoleh hasil rata-rata yang dapat dilihat pada tabel 1 dibawah ini.

Tabel 1.Data Kasar Hasil Penelitian

\begin{tabular}{|c|c|c|c|c|}
\hline Sampel & $\begin{array}{c}\text { Kontrol }(-) \\
(\mu \mathrm{m})\end{array}$ & $\begin{array}{c}\text { Kontrol }(+) \\
(\mu \mathrm{m})\end{array}$ & $\begin{array}{c}\text { CPP- } \\
\text { ACP } \\
(\mu \mathrm{m})\end{array}$ & $\begin{array}{c}\text { Novamin } \\
(\mu \mathrm{m})\end{array}$ \\
\hline 1 & 116,80 & 105,45 & 86,27 & 41,54 \\
\hline 2 & 140,6 & 115,7 & 82,7 & 33,04 \\
\hline 3 & 148,88 & 135,74 & 89,3 & 31,33 \\
\hline 4 & 192,07 & 117,53 & 83,83 & 37,88 \\
\hline 5 & 205,9 & 138,41 & 87,48 & 65,23 \\
\hline 6 & 171,93 & 129,43 & 96,47 & 58,53 \\
\hline
\end{tabular}

Tabel 2. Hasil Rerata Kedalaman Lesi Demineralisasi Tiap Kelompok

\begin{tabular}{|c|c|c|c|}
\hline $\begin{array}{c}\text { KELOMPOK } \\
\text { SAMPEL }\end{array}$ & $\mathrm{N}$ & $\overline{\mathrm{X}}$ & $\mathrm{SD}$ \\
\hline KONTROL (-) & 6 & 162,7 & 33,46 \\
\hline KONTROL (+) & 6 & 123,71 & 12,87 \\
\hline CPP - ACP & 6 & 87,68 & 4,93 \\
\hline NOVAMIN & 6 & 44,59 & 14,03 \\
\hline
\end{tabular}

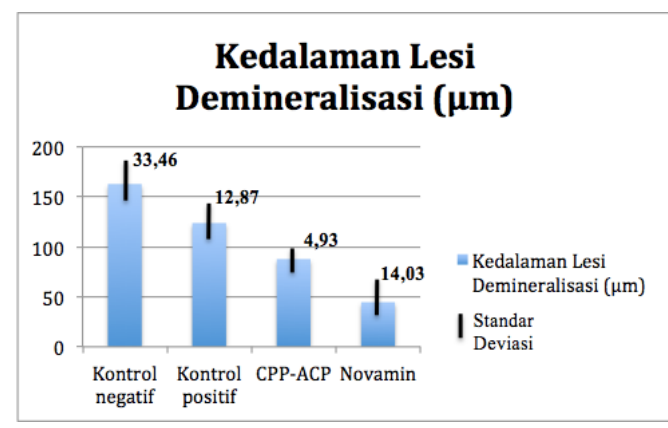

Gambar 1. Grafik Hasil Rerata Kedalaman Lesi Demineralisasi Tiap Kelompok Sampel

Berdasarkan grafik diatas dapat dilihat perbandingan kedalaman lesi demineralisasi pada masing - masing kelompok, dimana kelompok kontrol negatif memiliki nilai kedalaman lesi tertinggi disusul oleh kelompok kontrol positif, kelompok CPP-ACP, dan kelompok Novamin sebagai kelompok yang memiliki nilai kedalaman lesi paling rendah.

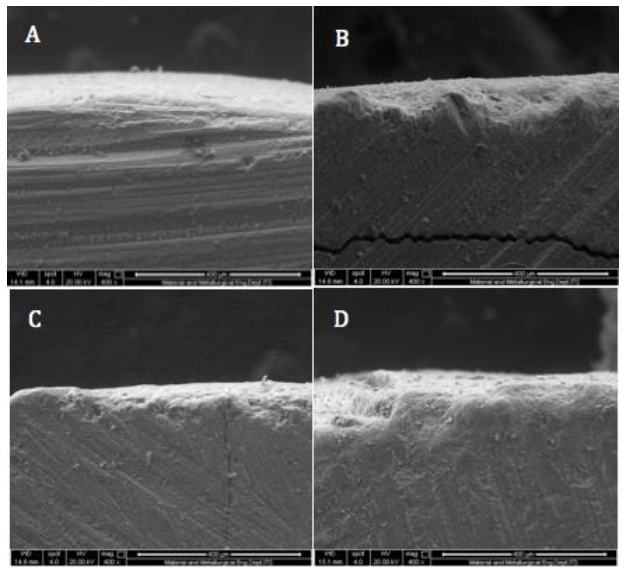

Gambar 2. Gambaran Hasil Uji SEM pada kelompok kontrol negatif (A), kontrol positif

(B), CPP-ACP (C), Novamin (D)

Pada gambar diatas dapat dilihat gambaran hasil uji SEM pada masing masing kelompok. Pada semua kelompok terlihat gambaran irregular di permukaan enamel, pada kelompok kontrol negatif (A) tampak gambaran irregular yang paling besar kemudian gambaran irregular yang lebih kecil pada kelompok kontrol positif (B) dan kelompok CPP-ACP (C) dan gambaran ireegular terkecil pada kelompok Novamin (D).

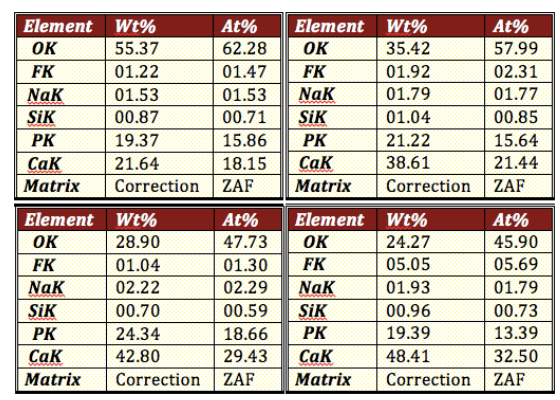

Gambar 5.3 Tabel Hasil Uji EDX pada kelompok kontrol negatif (kiri-atas), kontrol positif (kanan-atas), CPP-ACP (kiri-bawah), Novamin (kanan-bawah)

Pada gambar diatas dapat dilihat tabel hasil uji EDX pada masing masing kelompok. Pada semua kelompok terlihat jumlah kandungan kalsium $(\mathrm{CaK})$, fosfor $(\mathrm{PK})$ dan silika (SiK) yang terdapat pada tiap sampel. Tampak kandungan kalsium dan silika yang terbesar terdapat pada kelompok 
Novamin, diikuti oleh CPP-ACP, kontrol positif dan yang terkecil pada kontrol negatif.

\section{Analisa Statistik Data Hasil Penelitian}

\section{Hasil Uji Normalitas}

Sebelum dilakukan uji analisis antar kelompok penelitian, maka dilakukan uji normalitas terlebih dahulu pada masing - masing kelompok. Uji normalitas pada penelitian ini menggunakan uji KolmogorovSmirnov, selain itu dilakukan pula uji homogenitas. Dari tabel 3 dapat dilihat bahwa data yang didapat pada keseluruhan kelompok penelitian berdistribusi normal ( $>00,05)$. Uji homogenitas diukur dengan levene test dengan tingkat kemaknaan sebesar 0,05 ; maka semua data bersifat homogen $(\mathrm{p}<0,05)$.

Tabel 3. Hasil Uji Kolmogorov-Smirnov dan Levene Test

\begin{tabular}{|c|c|c|}
\hline $\begin{array}{c}\text { Kelompok } \\
\text { Penelitian }\end{array}$ & $\begin{array}{c}\text { Signifikansi } \\
\text { Normalitas (p) }\end{array}$ & $\begin{array}{c}\text { Levene } \\
\text { Test }\end{array}$ \\
\cline { 1 - 2 } Kontrol (-) & 0,998 & \multirow{2}{*}{$\mathrm{P}<0,05$} \\
\cline { 1 - 2 } Kontrol (+) & 0,987 & \\
\cline { 1 - 2 } CPP-ACP & 0,964 & \\
\hline Novamin & 0,838 & \\
\hline
\end{tabular}

\section{Hasil Uji Kruskal-Wallis Antar Kelompok}

Hasil uji antar semua kelompok menggunakan Kruskal-Wallis antara kelompok kontrol negatif, kelompok kontrol positif, kelompok CPP-ACP, dan kelompok Novamin didapatkan hasil bahwa antara semua kelompok perlakuan terdapat perbedaan yang bermakna. Hasil uji Kruskal-Wallis semua kelompok dapat dilihat pada tabel dibawah ini.

Tabel 4. Uji Kruskal-Wallis

\begin{tabular}{|l|l|r|r|}
\hline & Kelompok & N & Mean \\
\hline \multirow{4}{*}{$\begin{array}{l}\text { Kedalaman } \\
\text { Lesi }\end{array}$} & Kontrol neg & 6 & 20.83 \\
\cline { 2 - 4 } & Kontrol Pos & 6 & 16.17 \\
\cline { 2 - 4 } & CPP - APP & 6 & 9.50 \\
\cline { 2 - 4 } & Novamin & 6 & 3.50 \\
\hline & Total & 24 & \\
\hline
\end{tabular}

\begin{tabular}{|l|r|}
\hline & Kedalaman Lesi \\
\hline Chi-Square & 20.747 \\
\hline df & 3 \\
\hline Asymp. Sig. & .000 \\
\hline
\end{tabular}

*signifikansi $(\mathrm{p}<0,05)$

Hasil uji Post Hoc menunjukkan terdapat perbedaan yang bermakna antar tiap kelompok, hal ini ditunjukkan dengan nilai signifikansi yang lebih kecil dari $0,05 \quad(\mathrm{p}<0,05)$. Hasil uji Post Hoc antar tiap kelompok dapat terlihat pada tabel dibawah ini.

Tabel 5. Uji Post Hoc

\begin{tabular}{|c|c|c|c|c|}
\hline KELOMPOK & \multicolumn{4}{|c|}{ P (signifikansi) $<0,05$} \\
\cline { 2 - 5 } & $\begin{array}{c}\text { KONTROL } \\
(-)\end{array}$ & $\begin{array}{c}\text { KONTROL } \\
(+)\end{array}$ & $\begin{array}{c}\text { CPP- } \\
\text { ACP }\end{array}$ & $\begin{array}{c}\text { NOVA } \\
\text { MIN }\end{array}$ \\
\hline KONTROL (-) & - & 0,012 & 0,000 & 0,000 \\
\hline KONTROL (+) & 0,012 & - & 0,021 & 0,000 \\
\hline CPP-ACP & 0,000 & 0,021 & - & 0,005 \\
\hline NOVAMIN & 0,000 & 0,000 & 0,005 & - \\
\hline
\end{tabular}

Dari hasil uji Tukey pada tabel dibawah ini dapat dilihat bahwa bahan Novamin menurunkan lesi demineralisasi paling tinggi dibandingkan CPP-ACP dan kelompok kontrol positif serta kelompok kontrol negatif.

Tabel 6. Uji Tukey HSD Kedalaman Lesi Demineralisasi

\begin{tabular}{|l|c|c|c|c|c|}
\hline \multirow{2}{*}{ Kelompok } & N & \multicolumn{5}{|c|}{ Signifikansi = 0.05 } \\
\cline { 2 - 6 } & 1 & 2 & 3 & 4 & 1 \\
\hline Novamin & 6 & 44.5917 & & & \\
\hline CPP - APP & 6 & & 87.6750 & & \\
\hline Kontrol (+) & 6 & & & 123.7100 & \\
\hline Kontrol (-) & 6 & & & & 162.6967 \\
\hline
\end{tabular}

\section{DISKUSI}

Proses demineralisasi dan remineralisasi merupakan proses yang terus menerus berlangsung dalam rongga mulut. Demineralisasi gigi adalah larutnya mineral enamel gigi akibat konsentrasi asam yang mempunyai $\mathrm{pH}$ di bawah 5,5 lebih tinggi pada permukaan enamel dari pada di dalam enamel. ${ }^{4}$ Proses demineralisasi akan berhenti jika 
konsentrasi asam rendah dan konsentrasi kalsium atau fosfor dalam saliva kembali tinggi sehingga terjadi proses remineralisasi. ${ }^{1,2}$ Demineralisasi yang terjadi terus-menerus akan membentuk porositas pada permukaan enamel dan mengarah pada terjadinya keadaan patologis. $^{2}$

Demineralisasi merupakan proses hilangnya ion-ion mineral dari enamel gigi. Kandungan mineral utama dari enamel adalah hydroxyapatite (HA) yang terdiri dari $\mathrm{Ca}_{10}\left(\mathrm{PO}_{4}\right)_{6}(\mathrm{OH})_{2}$. Sejumlah ion mineral dapat hilang dari hidroksiapatit tanpa merusak integritas strukturalnya. Enamel yang terdemineralisasi lebih peka terhadap panas, dingin, tekanan, serta rasa sakit dibanding enamel normal. ${ }^{12}$

Pada lingkungan netral, HA seimbang dengan lingkungan saliva yang tersaturasi dengan ion $\mathrm{Ca}^{2+}$ dan $\mathrm{PO}_{4}{ }^{3-}$. HA reaktif terhadap ion hidrogen dengan $\mathrm{pH} \leq 5.5$ yang merupakan $\mathrm{pH}$ kritis untuk HA. $\mathrm{H}^{+}$ bereaksi dengan kelompok fosfat dalam lingkungan saliva yang dekat dengan permukaan kristal secara cepat. Proses itu dapat dideskripsikan sebagai konversi $\mathrm{PO}_{4}{ }^{3-}$ menjadi $\mathrm{HPO}_{4}{ }^{2-}$ dengan tambahan $\mathrm{H}^{+}$dan pada waktu yang sama $\mathrm{H}^{+}$disangga (mengalami buffering). $\mathrm{HPO}_{4}{ }^{2-}$ kemudian tidak dapat berkontribusi terhadap keseimbangan HA normal sehingga kristal HA larut. Hal ini disebut dengan demineralisasi. $^{12}$

Reaksi yang terjadi pada demineralisasi enamel adalah sebagai berikut:

$\mathrm{Ca}_{10}\left(\mathrm{PO}_{4}\right)_{6}(\mathrm{OH})_{2} \rightarrow 8 \mathrm{H}^{+} 10 \mathrm{Ca}^{2+}+6 \mathrm{HPO}^{-}+2 \mathrm{H}_{2} \mathrm{O}$

Remineralisasi merupakan proses pengembalian ion-ion mineral ke dalam struktur hidroksiapatit. Ion-ion yang hilang pada proses demineralisasi dapat dikembalikan apabila $\mathrm{pH}$ dinetralkan serta terdapat ion $\mathrm{Ca}^{2+}$ dan $\mathrm{PO}_{4}{ }^{3-}$ yang cukup di lingkungan. Dissolusi produk apatit dapat mencapai netralitas melalui buffering, sedangkan ion $\mathrm{Ca}^{2+}$ dan $\mathrm{PO}_{4}{ }^{3-}$ pada saliva dapat menghambat proses pelarutan melalui common ion effect. Hal ini mengakibatkan pembangunan kembali partly dissolved apatite crystals dan disebut dengan remineralisasi. Interaksi ini dapat ditingkatkan dengan keberadaan ion fluoride pada daerah reaksi. $^{12}$

Pada penelitian ini diukur kedalaman lesi demineralisasi yang terbentuk pada enamel gigi dimana pada setiap kelompok sampel diberi perlakuan yang berbeda. Bahan yang digunakan untuk mengurangi lesi demineralisasi yang terbentuk adalah CPP-ACP yang terkandung dalam GC Tooth Mousse ${ }^{\mathrm{TM}}$ dan Novamin yang terkandung dalam pasta gigi Sensodyne ${ }^{\mathrm{TM}}$. Kedua bahan ini memiliki fungsi untuk menghambat lesi demineralisasi dengan meningkatkan remineralisasi pada enamel.

Novamin merupakan kalsium sodium fosfosilikat yang termasuk dalam kelas bioaktif glass. Kandungan mineral sintetis sodium, kalsium, fosfor, dan silika (sodium kalsium fosfosilikat) berkontak dengan saliva atau air dan secara langsung akan melepaskan ion sodium, kalsium, fosfor kedalam saliva yang berfungsi sebagai remineralisasi dari permukaan gigi. Tidak seperti teknologi kalsium fosfat lainnya, ion - ion yang dilepaskan bioaktif glass akan membentuk hydroxycarbonate apatite (HCA) secara langsung tanpa melalui fase terbentuknya amorphous calcium phosphate intermediate. ${ }^{10}$ Partikel partikel ini akan melekat pada permukaan gigi dan terus melepaskan ion - ion dan melakukan proses remineralisasi pada permukaan gigi 
segera setelah diaplikasikan. Bioaktif glass dalam lingkungan basah akan bereaksi dengan cepat dalam 3 fase, yaitu perlekatan dan pertukaran kation, pelarutan $\mathrm{SiO} 2$, dan presipitasi kalsium dan fosfat membentuk lapisan apatit. Reaksi ionisasi dari Novamin membentuk kristal hidroksiapatit adalah sebagai berikut:

$5 \mathrm{Ca}^{2+}+3 \mathrm{PO}_{4}{ }^{3-}+\mathrm{OH}^{-} \rightarrow \mathrm{Ca}_{5}\left(\mathrm{PO}_{4}\right)_{3}(\mathrm{OH})$

Ikatan yang terbentuk antara deposit Novamin dengan permukaan enamel membentuk ikatan adhesif yang cukup kuat dan memiliki ukuran partikel yang besar sehingga tidak mudah terlepas apabila terkena bilasan air. ${ }^{13}$

CPP-ACP mempunyai efek positif terhadap remineralisasi enamel. Dimana mekanisme antikariogenik yang dihasilkan oleh CPP-ACP adalah merupakan suatu proses terlokalisasinya ion kalsium dan fosfat pada permukaan gigi, sehingga menjaga berlangsungnya proses buffer oleh saliva. Oleh karena itu hal ini membantu untuk mempertahankan keadaan netral pada enamel gigi, yang kemudian akan menurunkan proses demineralisasi, dan meningkatkan remineralisasi. ${ }^{8,9}$

Pada penelitian ini setiap sampel diberi perlakuan pendahuluan berupa perendaman dalam larutan demineralisasi selama 4 hari sehingga terbentuk lesi demineralisasi, kemudian kelompok pertama direndam dalam larutan akua bidestilata, kemudian dilakukan uji SEM, kelompok ini sebagai kontrol negatif. Kelompok kedua sebagai kontrol positif diberi perlakuan $\mathrm{pH}$ cycling menggunakan larutan saliva buatan dan larutan demineralisasi buatan selama 10 hari. Kelompok ketiga diberi perlakuan pengulasan bahan CPP-ACP kemudian dilakukan $\mathrm{pH}$ cycling, sedangkan kelompok keempat diberi perlakuan pengulasan bahan Novamin dan dilakukan $\mathrm{pH}$ cycling.
Tujuan dilakukannya $\mathrm{pH}$ cycling pada penelitian ini adalah untuk menyamakan kondisi dalam rongga mulut dimana selalu terjadi proses demineralisasi dan remineralisasi yang berlangsung secara terus menerus. Siklus $\mathrm{pH}$ cycling yang dilakukan mengikuti siklus Ittagharun (2010) dimana dilakukan perendaman dalam larutan demineralisasi selama 3 jam, kemudian dilakukan perendaman dalam larutan remineralisasi selama 2 jam, dilanjutkan perendaman kembali dalam larutan demineralisasi selama 3 jam dan perendaman dalam larutan remineralisasi selama 16 jam. Siklus ini dilakukan selama 10 hari karena penelitian ini menggunakan sampel gigi manusia. ${ }^{11}$

Setelah proses perlakuan dilakukan selama 10 hari, semua sampel dipersiapkan untuk pengukuran SEM(EDX) dengan cara memotong sampel dengan ukuran $2 \times 2 \mathrm{~mm}$ menggunakan diamond disc dan direkatkan pada carbon disc. Setelah itu, sampel dilakukan proses coating dan diuji dengan alat SEM(EDX) untuk mengukur kedalaman lesi yang terbentuk pada setiap sampel penelitian.

Data hasil penelitian yang didapat dari uji SEM dilakukan uji statistik untuk melihat distribusi data dan homogenitas data. Setelah data diuji didapatkan hasil distribusi normal dan data homogen, hal ini berarti validitas data tercapai sehingga dapat dilanjutkan untuk uji statistik lainnya yang berfungsi untuk melihat ada tidaknya perbedaan yang signifikan antar kelompok penelitian.

Dari hasil uji statistik KruskalWallis didapatkan hasil adanya perbedaan yang bermakna pada semua kelompok, kemudian pada tes Post Hoc didapatkan perbedaan yang bermakna antar variabel penelitian didapatkan kedalaman lesi demineralisasi kelompok kontrol 
negatif paling tinggi. Hal ini disebabkan karena tidak terjadi fungsi remineralisasi dari enamel karena setelah proses perendaman dalam larutan demineralisasi, sampel disimpan dalam larutan akuabides yang tidak mengandung mineral mineral pembangun kristal hidroksiapatit enamel sehingga tidak terjadi proses remineralisasi. Ion-ion yang hilang pada proses demineralisasi tidak dapat dikembalikan walaupun $\mathrm{pH}$ dinetralkan serta tidak terdapat ion $\mathrm{Ca}^{2+}$ dan $\mathrm{PO}_{4}{ }^{3-}$ yang cukup $\mathrm{di}$ lingkungan. ${ }^{12}$ Selain itu, proses demineralisasi akan berhenti jika konsentrasi asam rendah dan konsentrasi kalsium atau fosfor dalam saliva kembali tinggi sehingga terjadi proses remineralisasi, dimana hal ini tidak terjadi pada perendaman dalam akuabides. $^{1,2}$ Lesi demineralisasi yang terbentuk dalam kelompok ini terlihat dengan ukuran paling besar.

Pada kelompok kontrol positif didapatkan hasil ukuran kedalaman lesi demineralisasi yang terbentuk lebih rendah dari kelompok kontrol negatif tetapi lebih tinggi dari kelompok CPPACP dan kelompok Novamin. Hal ini disebabkan pada kelompok kontrol positif dilakukan $\mathrm{pH}$ cycling menggunakan larutan saliva buatan dan larutan demineralisasi buatan. Dalam larutan saliva buatan terdapat mineral - mineral pembangun kristal hidroksiapatit yaitu kalsium dan fosfor, sehingga larutan saliva buatan akan berfungsi dalam proses remineralisasi dari lesi demineralisasi yang terbentuk sebelumnya. Tetapi fungsi remineralisasi pada kelompok penelitian ini hanya berasal dari larutan saliva buatan tanpa adanya bahan aktif lainnya yang membantu proses remineralisasi. ${ }^{1,2,11}$

Pada kelompok CPP-ACP, hasil ukuran kedalaman lesi demineralisasi yang diukur lebih kecil dari kelompok kontrol positif dan negatif, tetapi lebih besar dari kelompok Novamin. Hal ini disebabkan oleh fungsi remineralisasi dari bahan CPP-ACP dimana bahan ini bekerja dengan ikatan CPP yang mampu menjaga kalsium dan fosfat pada saliva tetap dalam keadaan amorf non-kristalin yang artinya stabil, kemudian ion kalsium dan fosfat dapat dengan mudah beradhesi ke enamel gigi sehingga terbukti mengurangi risiko demineralisasi enamel dan membantu proses remineralisasi enamel gigi. ${ }^{14}$

Aplikasi CPP-ACP pada permukaan gigi dapat mencegah pelarutan dari ion kalsium dan fosfat. Selain itu, CPP-ACP juga bertindak sebagai penampung dari kalsium dan fosfat dan menjaga larutan tetap berada pada kondisi tersaturasi dan mempertahankan buffer saliva dimana kondisi enamel menjadi netral, sehingga terjadi remineralisasi dan proses demineralisasi berkurang. ${ }^{7}$ Tetapi deposit yang dibentuk oleh CPP-ACP ini berukuran kecil dan kurang adhesif terhadap permukaan enamel sehingga mudah terlepas bila terkena bilasan air. ${ }^{13}$

Pada kelompok Novamin terlihat pengurangan lesi demineralisasi paling besar dibandingkan kelompok lainnya. Hal ini disebabkan karena bahan aktif Novamin bekerja ketika diaplikasikan pada permukaan enamel menyebabkan mineral sodium, kalsium, dan fosfor berkontak dengan saliva/ air sehingga menghasilkan ion sodium, kalsium, dan fosfor yang langsung membentuk kristal hidroksiapatit. ${ }^{15}$ Deposit yang terbentuk ini memiliki ukuran yang lebih besar dari deposit yang terbentuk oleh CPP-ACP dan memiliki daya perlekatan yang besar terhadap permukaan enamel gigi sehingga tidak mudah terlepas bila terkena bilasan air. $^{13}$

Berdasarkan penjelasan hasil penelitian dan sesuai dengan hasil uji Tukey diatas dapat disimpulkan bahwa 
kelompok bahan aktif Novamin memiliki kemampuan paling baik dalam menurunkan lesi demineralisasi enamel dibandingkan kelompok CPPACP, kelompok kontrol positif dan kelompok kontrol negatif.

\section{SIMPULAN}

Kemampuan bahan aktif Novamin dalam menurunkan lesi demineralisasi lebih baik dibandingkan CPP-ACP terlihat dari lesi demineralisasi pada kelompok Novamin lebih kecil dibandingkan kelompok CPP-ACP.

\section{DAFTAR PUSTAKA}

1. Ilyas M. 2006. Perbedaan kadar kalsium dalam saliva sebelum dan sesudah mengkonsumsi minuman ringan yang mengandung asam sitrat. JITEKGI. 3:96-9.

2. Prasetyo EA. 2005. Keasaman minuman ringan menurunkan kekerasan permukaan gigi. Dent. J. 38: 60-3.

3. Beatrice K, Gandara, Edmond L.T. 1999. Diagnosis and management of dental erosion. The Journal of Contemporary Dental Practice. 1: 1-17.

4. Dawes C. 2003. What is the critical $\mathrm{pH}$ and why does a tooth dissolve in acid. J Can Dent Assoc. 69 : 722-4.

5. Caufield WP, Yvonne W. 1984. pH-Dependent Bacteriocidal Effects of Acidulated Flouride Gels on Preformed Plaque Aggregates of Streptococcus mutans. Alabama : Institute of Dental Research and School of Dentistry. 26(6): 807-9

6. Lewis WC, Milgrom P. 2003. Pediatrics in Review. Journal of the American Academy of
Pediatrics. 24: 327-8

7. Guotao Wu, Xinqiang Liu, Yongfu Hou. 2010. Analysis of the effect of CPP-ACP tooth mousse on enamel remineralization by circularly polarized images. Angle Orthodontist. 80; 933-8.

8. Oshiro M, Yamaguchi K, Takamizawa T, Inage H, Watanabe T, Irokawa A, et al. 2007. Effect of CPP-ACP paste on tooth mineralization: an FE-SEM study. Journal of Oral Science. 49:115-20.

9. Kargul,B, Altinok, R. Welbury. 2012. The Effect of casein phosphopeptide-amorphous calcium phospate on enamel surface rehardening. An in vitro study. Eur J of Pediatr Dent. 13(2).P. 123-7.

10. Natasha M, Neeraj M, Vikram S, Deepak P, Nidhi M. 2011. Tooth remineralization using bioactive glass - A novel approach. Journal Academy Advance Dental Research. 2(2): 459.

11. Itthagarun A, King NM, Yuen-Man Cheung. 2010. The effect of nano-hydroxyapatite toothpaste on artificial enamel carious lesion progression: An in-vitro pH-cycling study. Hong Kong Dent J. 7:61-6.

12. Bio-Rad. 2008. Quick start Bradford protein assay - instruction manual.

13. Mehta AB, Kumari V, Jose R, Izadikhah V. 2014. Remineralization potential of bioactive glass and casein phosphopeptide-amorphous calcium phosphate on initial carious lesion: An in-vitro $\mathrm{pH}$-cycling study. J Conserv Dent. $17: 3-7$

14. Seiboth B, Hartl L, Pail M, Kubicek CP. 2003. D-xylose metabolism in hypocrea jecorina: loss of the xylitol dehydrogenase step can be partially compensated for by lad1-encoded Larabinitol-4-dehydrogenase. Eukaryot Cell. 2(5):867-75.

15. Narayana SS, et al. 2014. Remineralization efficiency of bioactive glass on artificially carious lesion an in-vitro study. Journal Indian Soc Pedod Prev Dent. 32:19-25. 